Original scientific paper - Izvorni znanstveni rad

UDK: 637.046

\title{
Relations between basic milk components and free fatty acid content in Holstein cow milk as lipolysis parameter
}

doi: $10.15567 /$ mljekarstvo.2015.0103

\author{
Luděk Stádník ${ }^{1 *}$, Jaromír Ducháček ${ }^{1}$, Renáta Toušová ${ }^{1}$, Jan Beran ${ }^{1}$, \\ Martin Ptáček ${ }^{1}$, Lenka Kouřimská
}

${ }^{1}$ Department of Animal Husbandry, Faculty of Agrobiology, Food and Natural Resources, Czech University of Life Sciences Prague, Kamýcká 129, 16521 Prague 6 - Suchdol, Czech Republic ${ }^{2}$ Department of Quality of Agricultural Products, Faculty of Agrobiology, Food and Natural Resources, Czech University of Life Sciences Prague, Kamýcká 129, 16521 Prague 6 - Suchdol, Czech Republic

Prispjelo - Received: 27.05.2014. Prihvaćeno - Accepted: 16.01.2015.

\begin{abstract}
The aim of this study was to evaluate in detail the relationship between the basic milk components (fat and protein percentage) and the free fatty acids (FFA) content, as indicators of spontaneous and/or induced lipolysis. The additional aim of the study was to compare the FFA content of milk with respect to spontaneous and induced lipolysis. Milking was carried out in herringbone parlour twice a day. In total, 540 milk samples were obtained for evaluation of spontaneous $(n=240)$ and induced lipolysis $(\mathrm{n}=300)$. The milk samples for determination of basic milk components and FFA (lipolysis) levels were collected during four subsequent lactation weeks. Milk samples for spontaneous lipolysis detection were taken directly in parlour immediately after milking using the ICAR methodology and subsequently grouped. Induced lipolysis was observed from bulk milk in time $0,1,2,3$, and 4 hours after milking (T0-T4). The evaluation of basic components and FFA content was carried on MILKOSCAN F120 (Foss Electronic; Denmark). Statistical evaluation was carried out using SAS 9.3. (SAS/STAT $\left.{ }^{\circledast} 9.3,2011\right)$. An increase of one percentage of milk fat was equal to $0.318 \mathrm{mmol}$ x $100 \mathrm{~g}^{-1}$ FFA decline (spontaneous lipolysis) or from 0.232 to $0.370 \mathrm{mmol} \mathrm{x} 100 \mathrm{~g}^{-1}$ FFA decline (induced lipolysis T0-T4) respectively. One percentage increase of milk protein was equal to 1.219 mmol x $100 \mathrm{~g}^{-1}$ FFA increase (spontaneous lipolysis) or 0.421 to $1.531 \mathrm{mmol} \mathrm{x} 100 \mathrm{~g} \mathrm{~g}^{-1} \mathrm{FFA}$ decrease (induced lipolysis T0 - T4) respectively. Significant differences $(\mathrm{P}<0.01)$ were detected among FFA content in relation to spontaneous and induced lipolysis evaluated during storage and cooling after milking. The minimal differences were detected between the FFA content during 4 hours cooling and storage of milk in the tank.
\end{abstract}

Key words: spontaneous lipolysis, induced lipolysis, milk fat percentage, milk protein percentage

\section{Introduction}

Milk is very important source of nutrients in human diet, therefore it is necessary to monitor its quality. Milk composition is affected in general by genotype (Stádník et al., 1999; Kadlecová et al., 2014), feeding system and nutrition level (Rego et al., 2009), systems of milking (Bobić et al., 2013), morphology of teat and udder (Szencziová et al.,
2013) as well as other factors. The milk fat is a key component of raw milk determining energy balance of cows (Kadlecová et al., 2014) as well as processing, technological, and nutritional quality of milk (Ducháček et al., 2014). It is also one of the most variable parts of raw milk at the same time (Ducháček et al., 2013). Milk fat is dispersed in the raw milk in the form of fat globules. Lipolysis 
changes in raw milk induce fission of triglycerides on glycerol and free fatty acids (FFA) via the lipase enzyme. Exactly an increase of FFA in the raw milk can affects negatively the sensorial and technological characteristics of raw milk. Moreover, the number of FFA in raw milk also depends on the size of the damaged fat globules as an indicator of lipolysis. We can describe two types of lipolytic changes in raw milk - spontaneous and induced lipolysis (Toušová et al., 2013). Spontaneous lipolysis is a natural and spontaneous process in the raw milk after milking influenced by the cow's individuality, level and compound of feed ratio (Chilliard et al., 2003; Cieslak et al., 2010), milking frequency (Wiking et al., 2006), energy balance (González et al., 2011) and by the microorganisms activity (Vyletělová et al., 2001). In contrast, induced lipolysis is based on mechanical damage of fat globules evoked by the mechanical stresses of the raw milk at milking process: pumping milk from milking parlour, delivering milk to the tanks, mixing the milk, storage and subsequent processing of the milk. The most of lipolytic changes occur during the first 24 hours in a cold milk (Miller and Puhan, 1985). The flow of milk after milking should not exceed the rate of 1 to $1.5 \mathrm{~m} \mathrm{x} \mathrm{s}^{-1}$ in view of the milk technology acquisition and storage. The flow of milk above $1.6 \mathrm{~m} \mathrm{x} \mathrm{s}^{-1}$ or especially over 2.7 $\mathrm{m} \mathrm{x} \mathrm{s}^{-1}$ increases FFA content which occurs mainly in the narrowing of the milk pipe sections (Peterková, 2002). FFA content as an indicator of lipolytic changes ranges commonly from 0.5 to $1.21 \mathrm{mmol} x 100$ $\mathrm{g}^{-1}$ (Hanuš et al., 2008; Wiking et al., 2006). The FFA increase in the milk causes deterioration of its technological parameters (Vyletělová et al., 2000). The raw milk, containing more than 1 mmol after 24 hours of storage (including stirring and cooling) cannot be considered as milk of high quality. The critical value of FFA content in raw milk with respect to its quality is $1.5 \mathrm{mmol} \mathrm{x} \mathrm{L}^{-1}$ (Deeth, 2006).

The breeding of dairy cattle is focused on the content of milk basic components (percentage of fat and protein). These two parameters also predict the milk realization (encashment, price). We can assume that the long-standing intensive breeding focused on higher milk content compounds (especially the milk fat) will increase the FFA content and therefore influence the technological quality of milk. We can also suppose that cooling and storage the milk before leaving the dairy farm can affect the lipolytic changes.
The aim of this study was to evaluate in detail the relations between the basic milk content compounds and the FFA content, as indicators of spontaneous and/or induced lipolysis. The additional aim of the study was to compare the FFA content in milk with respect to spontaneous and induced lipolysis during storage and cooling.

\section{Materials and methods}

\section{Animals and herd management}

A total of 30 Holstein cows (10 on the first, 10 on the second and 10 on the third and subsequent lactations) housed in stable of Czech University of Life Sciences were selected for evaluation of spontaneous lipolysis. The cows were loose housed in a cubicle straw-bedded barn. Nutrition was served in form a total mixed ratio (TMR) contained corn silage, lucerne haylage, straw, hay, lucerne hay, production mixture, draff, bakery waste, molasses and mineral supplements. The ingredient composition of the diet corresponded to the current level of individual daily milk yields and feeding rations were completely balanced for energy, protein, fat as well as mineral and vitamin content. Observed cows calved during one month period. Milking in this farm was carried out in herringbone parlour twice a day, at 4:00 am and 4:00 pm. The average daily milk yield was from 11.21 to $11.81 \mathrm{~L}$ with range from 2.3 to $19.8 \mathrm{~L}$ in individual days of collection.

Cooling and storage of milk after milking, was performed in standard conditions (ČSN ISO 2446, 2010) in two standard milk tank with a volume 6000 L (Packo; Pacovské strojírny; Czech Republic). Intensive cooling was performed in the first $150 \mathrm{~min}$. from end of milking.

\section{Milk sample collection and analysis}

The milk samples for determination of basic milk components (fat, protein) and free fatty acids levels (FFA; lipolysis) were collected during ten collection days within four subsequent weeks of lactation. Cows were from 23 to 44 days in milk during the observation.

The milk samples were collected in accordance with the official methodology of the milk performance 
recording system (Hering, 2007), in accordance with the ICAR Directive. Aliquot milk samples were collected for the evaluation of spontaneous lipolytic activity to standard sample bottles from morning milking. The samples were collected individually from each cow observed directly after milking and individual samples were subsequently mixed to four representative samples. Each representative sample was repeatedly analysed six times, representing 24 results in relation to spontaneous lipolysis from each sampling day.

Bulk milk samples were collected for evaluation of induced lipolysis from milk storage tanks in interval 0, 1, 2, 3 and 4 hours (T0, T1, T2, T3 and T4) after end of milking. Each bulk milk sample was analysed six times as well, it means 30 results in relation to induced lipolysis from each sampling day. In total, 540 milk samples was obtained for evaluation of spontaneous $(n=240)$ and induced lipolysis $(n=300)$. All milk samples were preserved (Broad Spectrum Microtabs II, DaF Control Systems, England; $0.02 \%)$ and cooled down $\left(5 \pm 1{ }^{\circ} \mathrm{C}\right)$.

The evaluation of basic components and FFA content (mmol x $100 \mathrm{~g}^{-1}$ ) was carried out in Czech University of Life Sciences laboratory on MILKOSCAN F120 (Foss Electronic; Denmark). This machine works on FTIR technology based on infrared absorbance (ČSN 57 0533, 1997).

\section{Statistical analysis}

Statistical evaluation of basic milk components and FFA (mmol x $\left.100 \mathrm{~g}^{-1}\right)$ contents was carried out using REG, CORR, and MIXED procedure of statistical software SAS 9.3. (SAS/STAT ${ }^{\circledR}$ 9.3, 2011). Akaike Information Criterion was used for the best model determination. Model equation for assessment differences in FFA contents between spontaneous lipolysis immediately after milking and induced lipolysis ( 0 to 4 hour after the end of milking) contained following effects: lipolysis (spontaneous, induced), days in milk, regression on fat, resp. protein content and daily milk yield.

$$
\begin{gathered}
\mathrm{Y}_{\mathrm{ij}}=\mu+\operatorname{LIP}_{\mathrm{i}}+\mathrm{b}_{1} \mathrm{x}(\mathrm{DIM})+\mathrm{b}_{2} \mathrm{x}(\mathrm{FAT})+\mathrm{b}_{3} \mathrm{x} \\
(\text { PROTEIN })+\mathrm{b}_{4} \mathrm{x}(\text { MILK })+\mathrm{e}_{\mathrm{ij}}
\end{gathered}
$$

Where:

$\mathrm{Y}_{\mathrm{ij}}=$ value of the dependent variable (FFA content)
LIP $_{i}=$ fixed effect of $i^{\text {th }}$ content of FFA in milk ( $\mathrm{i}=$ spontaneous lipolysis, $n=240$; induced lipolysis 0 hour, $\mathrm{n}=60$; or induced lipolysis 1 hour, $\mathrm{n}=60$; or induced lipolysis 2 hour, $\mathrm{n}=60$; or induced lipolysis 3 hour, $\mathrm{n}=60$; or induced lipolysis 4 hour, $\mathrm{n}=60$ )

$\mathrm{b}_{1} \mathrm{x}(\mathrm{DIM})=$ linear regression to days in milk

$b_{2} \times(F A T)=$ linear regression to fat content $(\%)$

$\mathrm{b}_{3} \mathrm{x}(\mathrm{PROTEIN})=$ linear regression to protein content $(\%)$

$\mathrm{b}_{4} \mathrm{x}(\mathrm{MILK})=$ linear regression to daily milk production (L)

$\mathrm{e}_{\mathrm{ij}}=$ residual error.

The statistical significant differences were observed on the levels $\mathrm{P}<0.05$ and $\mathrm{P}<0.01$.

\section{Results and discussion}

The entire study was performed during a one month period in a group of selected dairy cows at the same stage of lactation and similar milk yield. Thus effects of nutrition level, feed ratio compound and season were eliminated. According to Chilliard et al. (2003) all these factors influenced free fatty acid (FFA) content or rather lipolysis rate in milk samples. Mentioned statement was also confirmed in study Ozcan et al. (2014), who observed differences in the content of fatty acids in milk between periods of the year. The aim of the study was to evaluate relations between basic milk components and FFA content in raw milk with respect to the spontaneous and/or induced lipolysis activity using the linear regression functions and the correlation coefficients. The results are presented in Tables 1 and 2.

Based on the results presented in Table 1 it is evident, according to the regression articles of equations, that the percentage increase of milk fat was followed by different FFA decrease as subsequent sentence explained in more detail. An increase of one percentage of milk fat was equal to $0.318 \mathrm{mmol}$ $\mathrm{x} 100 \mathrm{~g}^{-1}$ FFA decrease (spontaneous lipolysis) or from 0.232 to $0.370 \mathrm{mmol} \times 100 \mathrm{~g}^{-1}$ FFA decline (induced lipolysis) respectively. The highest values of absolute and regression members in linear regression were observed immediately after the milking (T0 = $2.381-0.370 \mathrm{x})$ and after the first hour of milk cooling $(\mathrm{T} 1=2.299-0.350 \mathrm{x})$. The decrease of both 
Table 1. Relations between fat $(\%)$ and FFA $\left(\mathrm{mmol} \times 100 \mathrm{~g}^{-1}\right)$ content in raw milk $(\mathrm{P}<0.01)$

\begin{tabular}{|c|c|c|c|c|}
\hline \multicolumn{2}{|c|}{ Milk fat (\%) } & Regression equation $\left(\mathrm{mmol} \times 100 \mathrm{~g}^{-1}\right)$ & $\mathrm{r}^{2}$ & $\mathrm{r}$ \\
\hline \multicolumn{2}{|c|}{$\begin{array}{l}\text { Spontaneous lipolysis } \\
\qquad(\mathrm{n}=240)\end{array}$} & $y=1.998-0.318 x$ & 0.084 & -0.296 \\
\hline \multirow{6}{*}{$\begin{array}{l}\text { Induced } \\
\text { lipolysis }\end{array}$} & T0 $(\mathrm{n}=60)$ & $y=2.381-0.370 x$ & 0.248 & -0.498 \\
\hline & $\mathrm{Tl}(\mathrm{n}=60)$ & $y=2.299-0.350 x$ & 0.257 & -0.507 \\
\hline & $\mathrm{T} 2(\mathrm{n}=60)$ & $y=1.958-0.257 x$ & 0.175 & -0.418 \\
\hline & $\mathrm{T} 3(\mathrm{n}=60)$ & $y=1.872-0.232 x$ & 0.172 & -0.415 \\
\hline & $\mathrm{T} 4(\mathrm{n}=60)$ & $y=1.882-0.238 x$ & 0.124 & -0.351 \\
\hline & Total $(n=300)$ & $y=2.066-0.286 x$ & 0.186 & -0.431 \\
\hline
\end{tabular}

T0, T1, T2, T3, and T4 = induced lipolysis in time $0,1,2,3$, and 4 hours after milking; Total = average induced lipolysis; $\mathrm{r}^{2}=$ coefficient of determination; $\mathrm{r}=$ correlation coefficient

Table 2. Relations between protein (\%) and FFA ( $\left.\mathrm{mmol} \mathrm{x} 100 \mathrm{~g}^{-1}\right)$ content in raw milk

\begin{tabular}{|c|c|c|c|c|}
\hline \multicolumn{2}{|c|}{ Milk protein $(\%)$} & Regression equation $\left(\mathrm{mmol} \times 100 \mathrm{~g}^{-1}\right)$ & $r^{2}$ & $\mathrm{r}$ \\
\hline \multicolumn{2}{|c|}{$\begin{array}{c}\text { Spontaneous lipolysis } \\
(\mathrm{n}=240)\end{array}$} & $y=-2.806+1.219 x^{* *}$ & 0.137 & 0.375 \\
\hline \multirow[t]{6}{*}{ Induced lipolysis } & T0 $(\mathrm{n}=60)$ & $\mathrm{y}=5.933-1.531 \mathrm{x}^{* *}$ & 0.391 & -0.625 \\
\hline & $\mathrm{Tl}(\mathrm{n}=60)$ & $\mathrm{y}=3.476-0.775 \mathrm{x}^{* *}$ & 0.085 & -0.292 \\
\hline & $\mathrm{T} 2(\mathrm{n}=60)$ & $y=2.664-0.519 x$ & 0.056 & -0.236 \\
\hline & T3 $(\mathrm{n}=60)$ & $y=4.162-0.978 x^{* *}$ & 0.147 & -0.383 \\
\hline & $\mathrm{T} 4(\mathrm{n}=60)$ & $\mathrm{y}=2.342-0.421 \mathrm{x}$ & 0.029 & -0.170 \\
\hline & Total $(n=300)$ & $y=3.643-0.823 x^{* *}$ & 0.115 & -0.339 \\
\hline
\end{tabular}

T0, T1, T2, T3, and T4 = induced lipolysis in time 0, 1, 2, 3, and 4 hours after milking; Total = average induced lipolysis; $\mathrm{r}^{2}=$ coefficient of determination; $\mathrm{r}=$ correlation coefficient; ${ }^{*} \mathrm{P}<0.05 ;{ }^{* *} \mathrm{P}<0.01$

members was evident within 3 hours after milking in relation to induced milk fat lipolysis. These results were also confirmed by the correlation coefficients between milk fat and FFA content. However, Chen et al. (2003) and Deeth (2006) oppositely stated that lipolysis and lipase are active in all process of milking and storage. All the correlation coefficients presented in Table 1 were negative. The high and medium correlations ( $r=-0.507$ to $-0.350 ; \mathrm{P}<0.01$ ) were found in milk samples according to prolongation of storage, respectively induced lipolysis while the lower correlation $(\mathrm{r}=-0.296$; $\mathrm{P}<0.01)$ was detected in milk immediately after milking, it means in relation to spontaneous lipolysis. On the other hand, Hanuš et al. (2008) found no statistical significant differences between milk fat and FFA content in raw milk. Contrary, Pešek et al. (2006) described negative energy balance effect on the content of FFA, actually increase of the FFA content. On other hand, the size of the milk fat globule increases with increasing fat content in the milk probably because of a limitation in production of milk fat globules membrane (Wiking et al., 2004). The size of the milk fat globules has crucial influence on the stability and technological properties of milk (Månsson, 2008).

The similar results as presented in Table 1 can be observed in Table 2 . Thus the increase of protein percentage in milk was followed by decrease of FFA content. The only opposite tendency was marked 
in milk samples of spontaneous lipolysis. One percentage increase of milk protein was equal to 1.219 mmol x $100 \mathrm{~g}^{-1}$ FFA increase (spontaneous lipolysis) or from 0.421 to $1.531 \mathrm{mmol} \times 100 \mathrm{~g}^{-1} \mathrm{FFA}$ decrease (induced lipolysis) respectively. However, these results showed no tendency and were not statistically significant $(\mathrm{P}>0.05)$ after 2, respectively 4 hours of milk cooling. The correlation coefficients also confirmed mentioned results between the milk protein and FFA content. The calculated correlation coefficients ranged from $r=-0.625$ (induced lipolysis immediately after the end of milking - T0) to $r=$ 0.375 (spontaneous lipolysis). Hanuš et al. (2008) observed a significant relationship between the milk protein and FFA content in raw milk, which is in accordance with our study. Also Ye et al. (2004) confirmed relationship between the milk protein content and fat globules membrane, and thus subsequently with the content of FFA.

According to regression equations of induced lipolysis, results indicated the cooling of the raw milk did not increase the FFA content significantly, and thus maintain the technological quality of milk. Most of breeding programs specialized to dairy cows is focused to improve milk yield and basic components content in milk (Šafus et al., 2005). The minimalizing of FFA content in milk has not been the direct aim of breeding yet. Generally, it could be presumed the higher fat percentage in milk the higher risk of fat globules damage and higher FFA content. However, the results of regression analysis did not confirm this presumption. An indirect dependence was detected between basic milk components and FFA content. Therefore, these findings confirmed the correctness of dairy cattle breeding program applied in the Czech Republic in the sense of milk quality affecting. The higher content of milk fat and protein decreased FFA content in raw milk immediately after milking which improved technological and processing quality of the milk. Therefore the higher percentage of milk fat is not a necessary precursor of more intensive lipolytic changes in raw milk in our opinion.

However, the results of our study are in opposite with elderly results of Celestino et al. (1996) and Wiking et al. (2002), who observed increase in FFA content during storage potentially caused by other factors for example mixing and cooling tech- nology or the length of mixing, resp. cooling period.

The next aim of this study was to evaluate changes of FFA contents in milk samples according to spontaneous, respectively induced lipolysis during 4 hours after milking (T0 to T4). The entire MIXED model explained difference in dependent characteristics caused by individual effect significantly $(\mathrm{P}<0.01)$ and described $76 \%$ proportion of their variability $\left(r^{2}=0.76\right)$. All the effects used in the model equation were statistically significant $(\mathrm{P}<0.05$ to 0.01$)$.

The lipolytic intensity could be connected to improved integrity and resistance of the fat globules. More resistant fat globules in raw milk create a stable system more resistant to mechanical straining (damage). It can be assumed that these factors determine the FFA content during both spontaneous and induced lipolysis. Concurrently these factors are influenced by nutrition level, cattle handling, stress and by management of the milking (Hanuš et al., 2008).

The results of FFA content in milk samples with respect to spontaneous as well as induced lipolysis are presented in Table 3. The significantly higher values of FFA content (from +0.15 to $+0.17 \mathrm{mmol}$ $\left.\mathrm{x} 100 \mathrm{~g}^{-1} ; \mathrm{P}<0.01\right)$ were detected in milk during cooling, mixing and storage it means according to induced lipolysis compared to spontaneous. The FFA content in individual milk samples from spontaneous lipolysis was $0.77 \mathrm{mmol} \times 100 \mathrm{~g}^{-1}$. There was only a marginally increase of FFA content (from +0.01 to $\left.+0.02 \mathrm{mmol} \mathrm{x} 100 \mathrm{~g}^{-1} ; \mathrm{P}>0.05\right)$ together with prolonged time of milk storage. Therefore, the values of FFA content reached from 0.92 to $0.94 \mathrm{mmol}$ x $100 \mathrm{~g}^{-1}$ during milk storage and consequently induced lipolysis. Comparing average FFA content in raw milk with respect to spontaneous and induced lipolysis shows the damage of milk fat globules during farm technological processing. Therefore it is suitable to minimize the length of the milk pipelines or excessive mixing during cooling the milk.

The average FFA content in milk samples coming from spontaneous and induced lipolysis ranged from 0.68 to $1.21 \mathrm{mmol}^{\mathrm{x}} 100 \mathrm{~g}^{-1}$ (Wiking et al., 2006). Our findings corresponded with stated range as well as were in accordance with Toušová et al. (2013) who detected higher value of FFA content in milk from induced lipolysis compared to spontaneous ones. 
Table 3. Content of FFA (mmol x $\left.100 \mathrm{~g}^{-1}\right)$ in milk in relation to spontaneous and induced lipolysis

\begin{tabular}{lll}
\hline \multicolumn{2}{l}{ Spontaneous or induced lipolysis } & LSM \pm SELsm \\
\hline Spontaneous lipolysis $(\mathrm{n}=240)$ & $0.77 \pm 0.028^{\mathrm{A}}$ \\
\hline \multirow{3}{*}{ Induced lipolysis } & $\mathrm{T} 0(\mathrm{n}=60)$ & $0.92 \pm 0.019^{\mathrm{B}}$ \\
\cline { 2 - 3 } & $\mathrm{T} 1(\mathrm{n}=60)$ & $0.92 \pm 0.019^{\mathrm{B}}$ \\
\cline { 2 - 3 } & $\mathrm{T} 2(\mathrm{n}=60)$ & $0.93 \pm 0.019^{\mathrm{B}}$ \\
\cline { 2 - 3 } & $\mathrm{T} 3(\mathrm{n}=60)$ & $0.93 \pm 0.019^{\mathrm{B}}$ \\
\hline
\end{tabular}

LSM - least-squares means; SELsm - standard errors of the means; T0, T1, T2, T3, and T4 = induced lipolysis in time 0, 1, 2, 3, and 4 hours after milking; A,B - different superscript letters confirm statistical significance of difference among rows at the $\mathrm{P}<0.01$

Low FFA content at relatively high fat content can be explained by example less damage due to vibration as well (Czerniewicz et al., 2006).

\section{Conclusion}

Based on the results achieved in our study we can confirm relations between basic milk components and FFA content in cow raw milk. Mainly milk fat $\%$ content significantly influenced intensity of spontaneous as well as induced lipolysis. The results of FFA content in raw milk coming from induced lipolysis can be connected to fat globules degradation during the cow's milking, respectively mixing, cooling, and storage of the milk on the farm.

The results confirmed that higher content of basic milk component did not deteriorate milk technological quality expressed by FFA content. This is suitable confirmation of dairy cattle breeding program used in the Czech Republic in the sense of maintaining the technological quality of milk.

Significant differences $(\mathrm{P}<0.01)$ were found among FFA content in relation to spontaneous and induced lipolysis. These results indicate mechanical damage of the raw milk fat globules during pumping the milk to milk container. However, non-significant increase of FFA content in milk during 4 hours after milking confirm the appropriate way of milk storage on the evaluated farm.

\section{Acknowledgement}

The study was supported from the "S" grant of MŠMT ČR. We thank Mrs. Lois Russell for her editorial help with this manuscript.

\section{Osnovni sastav mlijeka i slobodne masne kiseline kao parametar lipolize mlijeka holstein krava}

\section{Sažetak}

Cilj istraživanja bio je detaljno ispitati odnose između osnovnih sastojaka mlijeka (udjela masti i proteina) i sastava slobodnih masnih kiselina (SMK), kao pokazatelja spontane $\mathrm{i} / \mathrm{ili}$ inducirane lipolize. Dodatni cilj bio je usporediti sastav SMK mlijeka s obzirom na spontane i inducirane lipolize. Mužnja je provedena $u$ izmuzištu tipa riblja kost dva puta dnevno. Analizirano je 540 uzoraka mlijeka, od čega za ocjenu spontane $(n=240)$ i inducirane $(n=300)$ lipolize. Prikupljeni su uzorci mlijeka za određivanje osnovnih sastojaka mlijeka i SMK (lipoliza) tijekom četiri uzastopna tjedna mužnje. Uzorci mlijeka za otkrivanje spontane lipolize uzeti su izravno u izmuzištu odmah nakon mužnje korištenjem ICAR metoda i nakon toga su grupirani. Inducirana lipoliza uočena je u uzorcima mlijeka $\mathrm{u}$ vremenu $0,1,2,3$, i 4 sata nakon mužnje (T0-T4). Procjena osnovnih sastojaka mlijeka i sadržaja SMK utvrđena je pomoću MILKOSCAN F120 (Foss Electronic; Denmark). Statistička analiza provedena je korištenjem programa SAS 9.3. (SAS/STAT ${ }^{\circledR}$ 9.3, 2011). Utvrđeno je da je povećanje udjela mliječne masti za $1 \%$ jednako smanjenju SMK od 0,318 mmol x $100 \mathrm{~g}^{-1}$ (spontana lipoliza) ili smanjenju SMK od 0,2320,370 mmol x $100 \mathrm{~g}^{-1}$ (inducirana lipoliza T0-T4). Povećanje udjela proteina za $1 \%$ jednako je porastu SMK od 1,219 mmol x $100 \mathrm{~g}^{-1}$ (spontana lipoliza) ili smanjenju SMK od 0,421-1,531 mmol x $100 \mathrm{~g}^{-1}$ (inducirana lipoliza T0-T4). Utvrđene su značajne razlike $(\mathrm{P}<0,01)$ između sadržaja SMK u odnosu na 
spontane i inducirane lipolize tijekom skladištenja i hlađenja mlijeka nakon mužnje. Minimalne razlike utvrđene su između sadržaja SMK tijekom 4 sata hlađenja i skladištenja mlijeka u spremniku.

\section{Ključne riječi: spontana lipoliza, inducirana lipoliza, udjel mliječne masti, udjel proteina mlijeka}

\section{References}

1. Bobić, T., Mijić, P., Gregić, M., Ivkić, Z., Baban, M. (2013): The influence of ordinal number and stage of lactation on milkability traits in Holstein cows, Mljekarstvo 63 (3), 172-179.

2. Celestino, E.L., Iyer, M., Roginski, H. (1996): The effects of refrigerated storage on the quality of raw milk. Australian Journal of Dairy Technology 51 (2-3), 59-63.

3. Cieslak, A., Kowalczyk, J. Czauderna, M., Potkanski, A., Szumacher-Strabel, M. (2010): Enhancing unsaturated fatty acids in ewe's milk by feeding rapeseed or linseed oil, Czech Journal of Animal Science 55 (11), 496-504.

4. Chen, L., Daniel, R.M., Coolbear, T. (2003): Detection and impact of protease and lipase activities in milk and milk powders, International Dairy Journal 13, 255-275. doi: dx.doi.org/10.1016/S0958-6946(02)00171-1

5. Chilliard, Y., Ferlay, A., Rouel, J., Lamberet, G. (2003): A review of nutritional and physiological factors affecting goat milk synthesis and lipolysis. Journal of Dairy Science 86 (5), 1751-1770. doi: dx.doi.org/10.3168/jds.S0022-0302(03)73761-8

6. Czerniewicz, M., Kruk, A., Kielczewska, K. (2006): Storage stability of raw milk subjected to vibration, Polish Journal of Food and Nutrition Sciences 15/56, 65-70.

7. ČSN 57 0533. (1997): Mléko - Stanovení látkového obsahu volných mastných kyselin. Praha. 8 p.

8. ČSN ISO 2446. (2010): Mléko - Stanovení obsahu tuku. Praha. 24 p.

9. Deeth, H.C. (2006): Lipoprotein lipase and lipolysis in milk, International Dairy Journal 16 (6), 555-562. doi: dx.doi.org/10.1016/j.idairyj.2005.08.011

10. Ducháček, J., Stádník, L., Beran, J., Okrouhlá, M., Vacek, M., Doležalová, M. (2013): Body condition score and milk fatty acid composition in early lactation of Czech Fleckvieh cows, Acta Universitatis Agriculturae et Silviculturae Mendeleianae Brunensis 61 (6), 1621-1628. doi: dx.doi.org/10.11118/actaun201361061621

11. Ducháček, J., Stádník, L., Ptáček, M., Beran, J., Okrouhlá, M., Čítek, J., Stupka, R. (2014): Effect of cow energy status on hypercholesterolemic fatty acids proportion in raw milk, Czech Journal of Food Science 32 (3), 273-279.
12. González, F.D., Muiňo, R., Pereira, V., Campos, R., Benedito, J.L. (2011): Relationship among blood indicators of lipomobilization and hepatic function during early lactation in high-yielding dairy cows, Journal of Veterinary Science 12 (3), 251-255. doi: dx.doi.org/10.4142/jvs.2011.12.3.251

13. Hanuš, O., Vegricht, J., Frelich, J., Macek, A., Bjelka, M., Louda, F., Janů, L. (2008): Analysis of raw cow milk quality according to free fatty acid contents in the Czech Republic, Czech Journal of Animal Science 53 (1), 17-30.

14. Hering, P. (2007): Metodický postup č. 1 - Odběr vzorků při kontrole mléčné užitkovosti. Českomoravská společnost chovatelů, a.s., dostupné z: http://www. cmsch.cz/store/2007-mpl.pdf.

15. Kadlecová, V., Němečková, D., Ječmínková, K., Stádník, L. (2014): The effects of polymorphism in the DGAT1 gene on energy balance and milk production traits in primiparous Holstein cows during the first six months of lactation, Bulgarian Journal of Agricultural Science 20 (1), 203-209.

16. Månsson, H.L. (2008): Fatty acids in bovine milk fat, Food \& Nutrition Research 52, 1-3. doi: dx.doi.org/10.3402/fnr.v52i0.1821

17. Miller, B., Puhan, Z. (1985): Das "Lipolysierbare/Fett als Indikator für die Fettschädigung in der Rohmilk, Schweiz Milchwissenschaft Forsehrung 15 (1), 10-17.

18. Ozcan, T., Yaslioglu, E., Kilic, I., Simsek, E. (2014): The influence of the season and milking time on the properties and the fatty acid composition of the milk in different dairy cattle farms, Mljekarstvo (in-press).

19. Pešek, M., Samková, E., Špička, J. (2006): Fatty acids and composition of their important groups in milk fat of Czech Pied cattle, Czech Journal of Animal Science 51 (5), 181-188.

20. Peterková, L. (2002): Podíl volných mastných kyselin v mléce, faktory ovlivňující jejich množství a možnosti stanovení. Problematika prvovýroby mléka XXVI, Medlov, 26-30.

21. Rego, O.A., Alves, S.P., Antunes, L.M., Rosa, H.J., Alfaia, C.F., Prates, J.A., Carita, A.R., Fonseca, A.J., Bessa, R.J. (2009): Rumen biohydrogenation-derived fatty acids in milk fat from grazing dairy cows supplemented with rapeseed, sunflower, or linseed oils, Journal of Dairy Science 92 (9), 4530-4540. doi: dx.doi.org/10.3168/jds.2009-2060

22. SAS Institute Inc. (2011): SAS/STATR 9.3 User's Guide. Cary, NC: SAS Institute Inc. 684 p.

23. Stádník, L., Louda, F. (1999): Vliv genetických parametrů býků zjištovaných ve Francii na užitkovost a reprodukci dcer dovezených a otelených v České republice, Czech Journal of Animal Science 44 (10), 433-439.

24. Szencziová I., Strapák, P., Stádník, L., Ducháček, J., Beran, J. (2013): Relationship of udder and teat morphology to milking characteristics and udder health determined by ultrasonographic examinations in dairy cows, Annals of Animal Science 13 (4), 783-795. doi: dx.doi.org/10.2478/aoas-2013-0053 
25. Šafus, P., Štípková, M., Stádník, L., Přibyl, J., Čermák, V. (2005): Sub-indexes for bulls of Holstein breed in the Czech Republic, Czech Journal of Animal Science 50 (6), 254-265.

26. Toušová, R., Stádník, L., Ducháček, J. (2013): Effect of season and time of milking on spontaneous and induced lipolysis in bovine milk fat, Czech Journal of Food Sciences. 31 (1), 20-26.

27. Ye, A., Anema, S.G., Singh, H. (2004): High-pressure-induced interactions between milk fat globule membrane proteins and skim milk protein in whole milk, Journal of Dairy Science 87 (12), 4013-4022. doi: dx.doi.org/10.3168/jds.S0022-0302(04)73542-0

28. Vyletělová, M., Ficnar, J., Hanuš, O. (2000): Effects of lipolytic enzymes Pseudomonas fluorescens on liberation of fatty acids from milk fat, Czech Journal of Food Science 18 (5), 175-182.

29. Vyletělová, M., Hanuš, O., Páčová, Z., Roubal, P., Kopunecz, P. (2001): Frequency of Bacillus bacteria in raw cow's milk and its relation to other hygienic parameters, Czech Journal of Animal Science 46, 260-267.
30. Wiking, L., Frøst, M.B., Larsen, L.B., Nielsen, J.H. (2002): Effects of storage conditions on lipolysis, proteolysis and sensory attributes in high quality raw milk, Milchwissenschaft 57 (4), 190-194.

31. Wiking, L., Stagsted, J., Björck, L., Nielsen, J.H. (2004): Milk fat globule size is affected by fat production in dairy cows, International Dairy Journal 14 (10), 909-913. doi: dx.doi.org/10.1016/j.idairyj.2004.03.005

32. Wiking, L, Nielsen, J.H., Båvius, A. K., Edvardsson, A., Svennersten-Sjaunja, K. (2006): Impact of milking frequencies on the level of free fatty acids in milk, fat globule size, and fatty acid composition, Journal of Dairy Science 89 (3), 1004-1009. doi: dx.doi.org/10.3168/jds.S0022-0302(06)72166-X 